\title{
LAJU DEKOMPOSISI BAHAN ORGANIK DAN PRODUKSI INVERTEBRATA AIR DI SUAKA PERIKANAN TELUK RASAU, SUMATERA SELATAN
}

\author{
Husnah dan Dessy Arisna \\ Peneliti pada Balai Riset Perikanan Perairan Umum, Mariana-Palembang \\ Teregistrasi I tanggal: 17 Juni 2010; Diterima setelah perbaikan tanggal: 20 Juli 2010; \\ Disetujui terbit tanggal: 30 Juli 2010
}

ABSTRAK

Pembukaan lahan di lahan banjiran untuk berbagai kepentingan, mempengaruhi morfologi, siklus hidrologi, dan karakteristik fisika kimia air seperti input dan dekomposisi bahan organik yang akhirnya akan mempengaruhi struktur organisme invertebrata air dan produksi ikan di rawa banjiran. Penelitian ini bersifat percobaan lapangan yang bertujuan untuk mengetahui laju dekomposisi bahan organik dan produksi invertebrata air dilakukan di tiga stasiun di Teluk Rasau, Sumatera Selatan pada bulan September sampai Nopember 2009. Laju dekomposisi bahan organik dan produksi invertebrata air dilakukan dengan metode jaring kantong (litter bag) berukuran $20 \times 10 \mathrm{~cm}$ dengan ukuran mata jaring $2 \mathrm{~mm}$. Daun dari tumbuhan yang dominan yaitu pohon serpang (Caesalpina sappan) yang hampir gugur dikumpulkan dan ditimbang bobot keringnya, dan $5 \mathrm{~g}$ dari daun tersebut dimasukan ke dalam jaring kantong. Pada masing-masing (stasiun) percobaan diletakan 40 kantong jaring dengan posisi 20 kantong diletakan pada kedalaman air $0 \mathrm{~m}$ (perbatasan air dan darat) dan 20 kantong pada kedalaman $75 \mathrm{~cm}$. Kantong diikatkan tiang kayu dan ditenggelamkan dengan menggunakan pemberat. Pengukuran jumlah bahan organik yang terdekomposisi dan produksi makrozoobenthos dilakukan pada minggu ke-2, 4, 6, 8, dan 10, dengan cara mengangkat empat kantong plastik pada masing-masing kedalaman. Contoh air diambil pada kedalaman $1 \mathrm{~m}$ dari dasar perairan dengan menggunakan kemmerer water sampler. Sebagian contoh dianalisis di lapangan (kedalaman air, kecerahan, suhu, $\mathrm{pH}$, dan oksigen terlarut) dan sebagian lagi akan dianalisis di laboratorium (dissolved organic carbon, nitrogen total, dan fosfor total. Persentase serasah daun serpang yang terdekomposisi selama 10 minggu pada kisaran 40-55\%. Koefisien laju dekomposisi serasah daun serpang pada muara Teluk Rasau yang berhubungan dengan Sungai Lempuing pada kedalaman $0 \mathrm{~cm}(\mathrm{k}=0,1586)$ lebih rendah dari stasiun lainnya baik pada kedalaman $0 \mathrm{~cm}$ ataupun $75 \mathrm{~cm}(\mathrm{k}=0,2076-0,2566)$. Produksi makrozobenthos di muara Teluk Rasau yang berhubungan dengan Sungai Lempuing baik pada kedalaman $0 \mathrm{~cm}$ ataupun $75 \mathrm{~cm}\left(9,25 ; 117,25 \mathrm{mg}\right.$ bobot kering/ $\left.\mathrm{m}^{2}\right)$ secara nyata lebih rendah dari stasiun lainnya (17,75-22,08 mg bobot kering $/ \mathrm{m}^{2} ; 260-807 \mathrm{mg}$ bobot kering $\left./ \mathrm{m}^{2}\right)$. Kedalaman air, suhu, alkalinitas total, dan unsur hara sangat mempengaruhi laju dekomposisi serasah dan produksi makrozoobenthos.

KATAKUNCI: laju dekomposisi, serasah, tumbuhan serpang, produksi invertebrata, rawa banjiran

$\begin{array}{ll}\text { ABSTRACT: } & \text { Decomposition rate of organic matter and invertebrate production of Teluk } \\ & \text { Rasau fisheries reserve area, South Sumatera. By: Husnah and Desi Arisna }\end{array}$

Clearance of floodplain area for multiple purposes influence morphology, hidrological cycle, and physical and chemical characteristics of water such as input and decomposition of organic matter in the waters. It finally affect the structure community of invertebrate and fish production. Experimental study in order to know decomposition rate of organic matter and aquatic invertebrate production was conducted at three sampling sites located in Teluk Rasau Fisheries Reserve Area of South Sumatera province from September to November 2009. Decomposition rate and invertebrate production was run with litter bag method. Leaf bags were constructed by placing $5 \mathrm{~g}$ of Caesalpina sappan in plastic with the size of $20 \times 10 \mathrm{~cm}$ and mesh bags (mesh size $2 \mathrm{~mm}$ ). Leaves were collected before abscission, air dried and stored. In each sampling sites, 20 litter bags were filled with dry leaves and placed on the sediment at water depth $0 \mathrm{~m}$ (transition between land and water), and another 20 litter bags were placed on the sediment at $0.75 \mathrm{~m}$ water depth. The litter bags were tied to the wood stake and anchored to the bottom. The leaf bags were tied together with a weighted rope and attached to a tree. Four replicate samples were removed after 2 days, to measure the leaching process, and then after 4 , 6, 8, and 10 weeks for organic matter decomposition rate and invertebrate production measurement. The bags were cut from the rope and immediately placed in sealed plastic bags and returned to the laboratory. In the laboratory, the leaves were rinsed and separated from the invertebrate. The leaves 
were sorted by genus, dried at $50^{\circ} \mathrm{C}$ and weighed. invertebrate were counted and identified to different taxonomic levels. Physical and chemical water quality parameters were measured both in and exsitu by collecting water samples with kemmmerer water sampler at $1 \mathrm{~m}$ depth above the bottom. Parameters measured insitu were the water depth, transparency, temperature, $\mathrm{pH}$ value, dissolved oxygen, while, dissolved organic carbon, total nitrogen, and total phosphorus were analyzed in the laboratory. Results indicated that decomposition rate of Caesalpina sappan leaves for 10 weeks was in the range of 40-55\%. The decomposition rate coefficient in the inlet of Teluk Rasau connevting to Lempuing River at depth $0 \mathrm{~cm}((k=0.1586)$ was less than that in other sampling sites both at depth ocm and $75 \mathrm{~cm}(k=0.2076-0.2566)$. Macrozoobenthos production in the inlet of Teluk Rasau connecting to Lempuing River at depth 0 and $75 \mathrm{~cm}\left(9.25 ; 117.25 \mathrm{mg}\right.$ dry weight $\left./ \mathrm{m}^{2}\right)$ were less than that in other sampling sites $\left(17.75-22.08 \mathrm{mg}\right.$ dry weight $/ \mathrm{m}^{2} ; 260-807 \mathrm{mg} \mathrm{dry}$ weight $\left./ \mathrm{m}^{2}\right)$. Decomposition rate and invertebrate production of Caesalpina sappan were affected by water depth, temperature, total alkalinity, and nutrient.

\section{KEYWORDS: $\quad$ decomposition rate, leave litter, Caesalpina sappan, invertebrate production, floodplain}

\section{PENDAHULUAN}

Bahan organik berperan penting sebagai sumber energi dan daur unsur hara pada perairan umum baik perairan umum pada tipe mengalir ataupun tergenang. Kontribusi bahan organik terhadap pasokan energi mencapai 30-75\% (Kaplan \& NewBold, 1993). Pada perairan umum, bahan organik baik yang berasal dari dalam perairan itu sendiri (autochnous) ataupun dari luar (allochtonous) merupakan komponen dasar metabolisme dalam perairan (Whitten et al., 1987; Findlay \& Sinsabaugh, 2003).

Bahan organik baik autochonous ataupun allochtonous pada umumnya terdiri atas tiga bentuk yaitu bahan organik berbentuk partikel kasar (coarse particulate organic matter), bahan organik berbentuk partikel halus (fine particulate organic matter) dan bahan organik terlarut (dissolved organic matter). Ketiga bentuk bahan organik tersebut mempengaruhi aliran energi pada ekosistem perairan umum dan akan mempengaruhi keanekaragaman hayati, produktivitas perairan dan produksi ikan (Braioni et al., 2001; Kaplan \& NewBold, 2003; Whitten et al., 1987). Dari ketiga bentuk bahan organik tersebut, dissolved organic matter merupakan salah satu bentuk bahan organik yang akhir dari proses mineralisasi menghasilkan unsur hara dan karbon yang dibutuhkan oleh organisme produser di perairan. Kandungan dissolved organic matter dalam suatu perairan dapat diukur melalui kandungan dissolved organic carbon.

Pada perairan rawa banjiran (floodplain), input bahan organik sebagian besar berasal dari hasil produktivitas primer tumbuhan riparian (riparian vegetation) dan makrofita. Namun hanya sebagian kecil dari fraksi bahan organik tersebut dikonsumsi oleh hewan air, selebihnya bahan organik tersebut mengalami penguraian (dekomposisi). Bahan organik yang pada beberapa fase dekomposisi, akan dikonsumsi oleh organisme detritifora seperti invertebrata air dan ikan (Braioni et al., 2001). Perubahan morfologi, siklus hidrologi, dan karakteristik fisika kimia air di rawa banjiran sebagai akibat pembukaan lahan akan mempengaruhi input dan dekomposisi bahan organik (Graca, 2001; Welcomme \& Hall, 2004) yang akhirnya akan mempengaruhi struktur organisme invertebrata air dan produksi ikan. Pembuatan konstruksi saluran air (kanal) untuk kegiatan perkebunan di rawa banjiran dapat meningkatkan keasaman air (Husnah, 2008). Peningkatan keasaman air dapat memperlambat laju dekomposisi serasah dan menurunkan jumlah total bahan organik di perairan.

Teluk Rasau adalah bagian dari daerah banjiran di Kabupaten Ogan Komering Ilir, Sumatera Selatan dengan sumber air berasal dari Sungai Komering yang mengalir ke arah utara menuju Desa Pedamaran. Perairan ini tergenang air sepanjang tahun dan merupakan wilayah perikanan daerah bernilai tinggi. Perairan di sekitar Teluk Rasau ini di lelang selama 12 bulan penuh. Teluk Rasau terhubungkan dengan Sungai Lempuing pada daerah perbatasan dua unit daerah lelang yaitu Sungai Aur (di bagian hilir) dan Laut Sekampung (di bagian hulu). Teluk Rasau merupakan daerah suaka perikanan khususnya jenis ikan yang bermigrasi untuk memijah baik secara lateral ataupun longitudinal. Perairan ini tertutup sepanjang tahun untuk aktivitas penangkapan ikan (Thomas et al., 1998). Pembukaan lahan rawa banjiran di sepanjang Sungai Lempuing untuk pertanian, perkebunan, dan pemukiman akan merubah struktur dan fungsi ekologi rawa banjiran di Sungai Lempuing tidak terkecuali perairan Teluk Rasau. Pembukaan lahan di rawa banjiran akan mempengaruhi input dan dekomposisi bahan organik yang akhirnya akan mempengaruhi komunitas invertebrata air dan ikan. Beberapa studi telah dilakukan di Teluk Rasau (Thomas et al., 1998; 
Hoggarth et al.,1999) khususnya mengenai peran dan manfaat suaka perikanan terhadap perikanan tangkap, namun informasi inputdan dekomposisi bahan organik dalam kaitannya dengan perubahan ekologi rawa banjiran terbatas.

Tujuan penelitian ini adalah untuk mengetahui laju dekomposisi bahan organik berasal dari tumbuhan riparian dan produksi invertebrata air di perairan suaka perikanan rawa banjiran Teluk Rasau.

\section{BAHAN DAN METODE}

\section{Pengumpulan Data}

Penelitian ini dilakukan bersifat percobaan di lapangan dimulai pada bulan September sampai Nopember 2009, dan analisis di laboratorium yang berlangsung dari bulan September sampai Desember 2009. Tiga stasiun percobaan ditentukan secara purposif yang didasarkan atas perbedaan habitat mikroskopik secara spasial (Gambar 1 dan Tabel 1).

Reservat Teluk Rasau, Desa Pedamaran VI

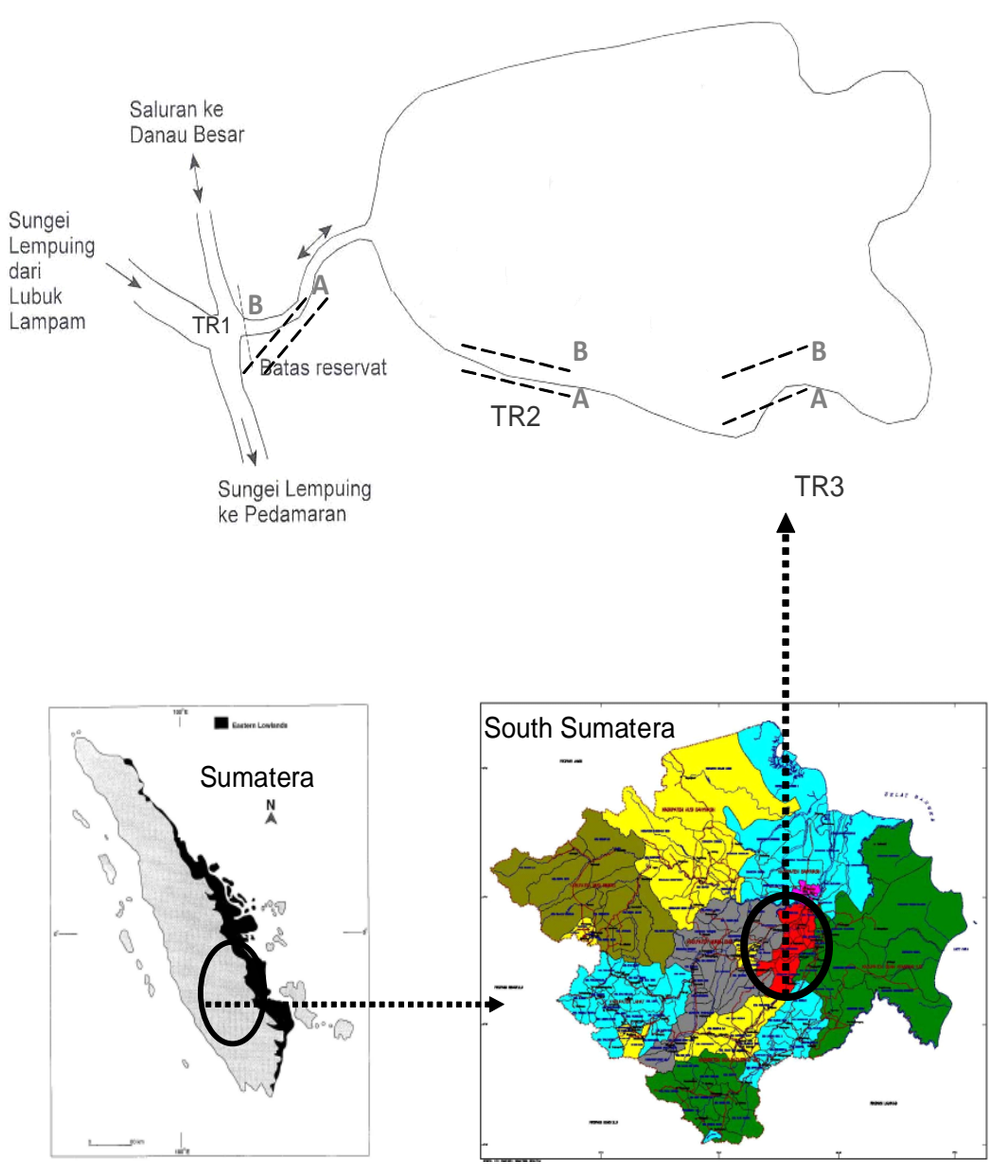

Gambar 1. Stasiun pengambilan contoh di Teluk Rasau, Kabupaten Ogan Komering llir, Sumatera Selatan. Muara Teluk Rasau di Sungai Lempuing (TR1), Teluk Rasau Tengah (TR2), dan Teluk Rasau dekat daerah perkebunan sawit (TR3). Kedalaman transisi (A) dan kedalaman $75 \mathrm{~cm}(\mathrm{~B})$. Posisi penempatan empat kantong jaring (-)

Figure 1. Sampling site in Teluk Rasau, Ogan Komering Ilir Regency, South Sumatera. Inlet of Teluk Rasau connected to Lempuing River (TR1), Middle of Teluk Rasau (TR2), Teluk Rasau closed to oil palm plantation. Transition depth $(A)$ and $75 \mathrm{~cm}$ water depth (B), litter bag position (—). 
Tabel 1. Koordinat dan karakteristik lingkungan stasiun pengambilan contoh di Teluk Rasau dan Sungai Lempuing, Kabupaten Ogan Komering llir, Sumatera Selatan

Table 1. Coordinate and environment characteristics of sampling sites in Teluk Rasau and Lempuing River, Ogan Komering llir Regency, South Sumatera

\begin{tabular}{|c|c|c|c|c|}
\hline No. & Stasiun/Station & $\begin{array}{l}\text { Kode } \\
\text { /Code }\end{array}$ & $\begin{array}{l}\text { Koordinat (lintang selatan } \\
\text { dan bujur timur)/ } \\
\text { Coordinates (latitude south } \\
\text { and longitude east) }\end{array}$ & $\begin{array}{l}\text { Karakteristik lingkungan/ } \\
\text { Environmental Characteristics }\end{array}$ \\
\hline 1. & $\begin{array}{l}\text { Inlet Teluk Rasau } \\
\text { (Sungai Lempuing) }\end{array}$ & TR1 & $\begin{array}{c}3^{\circ} 31^{\prime} 16.11^{\prime \prime} ; \\
104^{\circ} 51^{\prime} 53.94 "\end{array}$ & $\begin{array}{l}\text { Inlet sumber air dari Sungai Lempuing. } \\
\text { Sisi kiri dan kanan persawahan. }\end{array}$ \\
\hline 2. & Teluk Rasau Tengah & TR2 & $\begin{array}{l}3^{\circ} 31^{\prime} 3.91^{\prime \prime} \\
104^{\circ} 51^{\prime} 3.48 "\end{array}$ & $\begin{array}{l}\text { Hutan sekunder dominansi tumbuhan } \\
\text { vegetasi serpang. Tepian landai. }\end{array}$ \\
\hline 3. & Teluk Rasau Ujung & TR3 & $\begin{array}{l}3^{\circ} 30^{\prime} 53.51^{\prime \prime} \\
104^{\circ} 50^{\prime} 48.93^{\prime \prime}\end{array}$ & $\begin{array}{l}\text { Perkebunan sawit masyarakat. Tepian } \\
\text { landai dan terbukan. }\end{array}$ \\
\hline
\end{tabular}

Laju dekomposisi bahan organik dilakukan dengan metode litter bag yang terbuat dari kantong jaring berukuran $20 \times 10 \mathrm{~cm}$ dengan ukuran mata jaring 2 mm (Braioni et al., 2001; Alvarez et al., 2001). Contoh dedaunan berwarna kuning yang hampir gugur dari tumbuhan riparian jenis tumbuhan serpang (Caesalpinaceae) yang dominan di masing-masing stasiun dikumpulkan dan dibawa ke laboratorium untuk dibersihkan dan dikeringkan sampai bobot stabil dalam oven pada suhu $50^{\circ} \mathrm{C}$ selama 48 jam. Dedaunan kuning dengan bobot kering $5 \mathrm{~g}$ diletakan ke dalam masing-masing 120 kantong plastik. Pada masingmasing stasiun pengambilan contoh diletakan 20 kantong plastik pada kedalaman air $0 \mathrm{~m}$ (perbatasan air dan darat $(A)$ dan 20 kantong pada kedalaman 75 $\mathrm{cm}(B)$. Kantong plastik diikatkan tiang kayu dan ditenggelamkan dengan menggunakan pemberat. Pengukuran jumlah bahan organik yang terdekomposisi dilakukan pada minggu ke-2, 4, 6, 8, dan 10, dengan cara mengangkat empat kantong plastik pada masing-masing kedalaman dari masingmasing stasiun dan menyimpannya pada kantong plastik bersih yang tertutup, diawetkan dengan es dan dibawa ke laboratorium. Invertebrata air dan partikel debris dilepaskan dari dedaunan dengan membersihkan contoh tersebut dengan air bersih, disikat, dan disaring dengan menggunakan penyaring dengan lubang saringan berdiameter $250 \mu \mathrm{m}$ dan diawetkan dengan alkohol $70 \%$. Dedaunan yang tersisa dikeringkan pada suhu $50^{\circ} \mathrm{C}$ selama 48 jam, selanjutnya ditimbang. Makro invertebrata dihitung kelimpahan total dan biomassanya dengan cara mengeringkan dalam oven pada suhu $60^{\circ} \mathrm{C}$ selama 48 jam.
Contoh air diambil pada kedalaman $1 \mathrm{~m}$ dari dasar perairan dengan menggunakan kemmerer water sampler. Sebagian contoh dianalisis di lapangan (kedalaman air, kecerahan, suhu, $\mathrm{pH}$, dan oksigen terlarut) dan sebagian lagi akan dianalisis di laboratorium dissolved organic carbon, nitrogen total, dan fosfor total. Contoh daun dianalisis untuk karbon total, nitrogen total, dan fosfor total pada minggu ke0,6 , dan 10 dengan peralatan dan metode yang digunakan pada Tabel 2.

\section{Analisis Data}

Laju dekomposisi dihitung berdasarkan atas model eksponensial (Olson, 1963; Petersen \& Cummins, 1974) dalam Alvares et al. (2001):

$\mathrm{Mt}=$ Mo $e-k \mathrm{t}$ $(1$

di mana:

$\mathrm{Mt}=$ bobot daun tersisa pada waktu $\mathrm{t}(\mathrm{g})$

$\mathrm{Mo}=$ bobot daun saat awal $(\mathrm{g})$

$\mathrm{k}=$ koefisien dekomposisi

Untuk membandingkan regresi pada masingmasing stasiun digunakan analisis kovarian (ankova $(\mathrm{P}<0,05)$ (Zar, 1996 dalam Alvares et al., 2001). Sebelum dilakukan analisis kovarian, data ditransformasi secara logaritmik $(x+1)$. Setelah analisis kovarian dilakukan analisis multiple pairwise comparisons melalui tukeys post hoc test. Data kelimpahan makroinvertebrata ditransformasi secara logaritmik $(x+1)$ sebelum dilakukan analisis variance. Semua analisis statistik menggunakan program komputer Statistica Versi 6. 
Tabel2. Peralatan dan metode yang digunakan dalam pengukuran parameter fisik dan kimia air Table 2. Method and equipment used in physical and chemical water quality analysis

\begin{tabular}{|c|c|c|c|c|}
\hline No. & & rameter/Parameter & Peralatan/Equipment & Metode/Method \\
\hline \multirow[t]{5}{*}{1.} & Fisika & & & \\
\hline & & Suhu & Termometer & Visual \\
\hline & & Kecerahan & Secchi Disk & Visual \\
\hline & & Daya hantar listrik & Conductivity & Elektronik \\
\hline & & Kedalaman air & Echo depth & Akustik \\
\hline \multirow[t]{5}{*}{2.} & Kimia & $\begin{array}{l}\text { Kecepatan arus } \\
\mathrm{pH}\end{array}$ & $\begin{array}{l}\text { Flow meter } \\
\text { pH-meter }\end{array}$ & \\
\hline & & Oksigen terlarut & & Titrasi Winkler \\
\hline & & Dissolved organic carbon & & Combustion infrared \\
\hline & & Total nitrogen & Spectrofotometer & Disgetion $\mathrm{K}_{2} \mathrm{~S}_{2} \mathrm{O}_{8}$ \\
\hline & & Total fosfor & Spectrofotometer & Disgestion persulfat \\
\hline \multirow[t]{3}{*}{3.} & Biologi & Total karbon & & Gravimetrik \\
\hline & & Total nitrogen & Spectrofotometer & Micro kjeldhal \\
\hline & & Total fosfor & Spectrofotometer & $\begin{array}{l}\text { Wet disgestion molybdate dan } \\
\text { vanadate }\end{array}$ \\
\hline
\end{tabular}

\section{HASIL DAN BAHASAN}

Persentase serasah daun serpang yang terdekomposisi selama 10 minggu pada kisaran 40-
55\% (Gambar 2). Dekomposisi serasah vegetasi serpang secara signifikan $(P<0,01)$ sangat dipengaruhi oleh lokasi stasiun, kedalaman air, dan lamanya waktu dekomposisi (Tabel 3 dan Lampiran 1 dan 5).

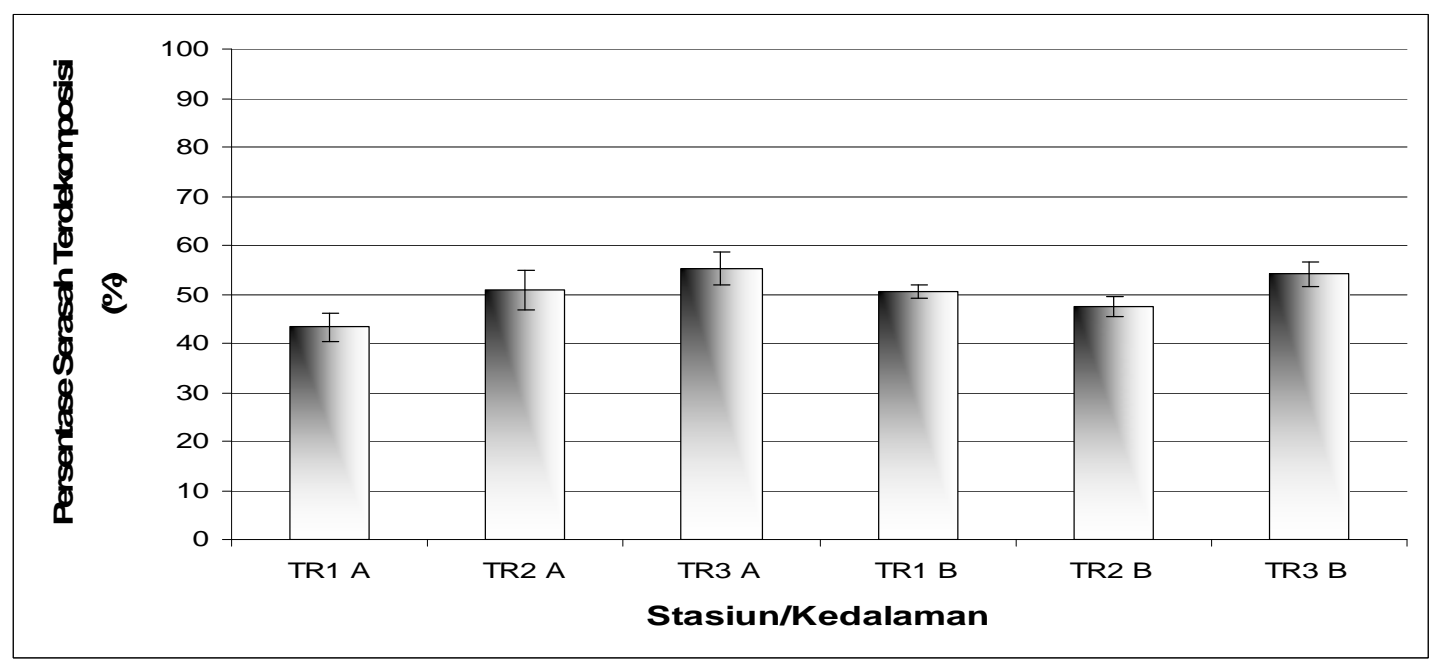

Gambar 2. Persentase daun serpang yang terdekomposisi setelah dipaparkan selama 10 minggu pada stasiun di Muara Teluk Rasau Sungai Lempuing (TR1) dan Lebak Teluk Rasau (TR2 dan TR3) pada kedalaman transisi (A) dan $75 \mathrm{~cm} \mathrm{(B).}$

Figure 2. Decomposition of serpang leaves (\%) after 10 week exposure in inlet of Teluk Rasau connected to Lempuing River (TR1), middle of Teluk Rasau (TR2), Teluk Rasau closed to oil palm plantation. Transition depth $(A)$ and $75 \mathrm{~cm}$ water depth $(B)$. 
Tabel 3. Nilai rata-rata koefisien (laju) dekomposisi serasah serpang pada berbagai stasiun (TR 1-3) dan kedalaman air $(A=$ kedalaman $0 \mathrm{~cm} /$ transisi, $B=$ kedalaman $75 \mathrm{~cm}$ ) selama 10 minggu

Table 3. The average of decomposition rate of serpang leaves at different sampling sites (TR1-TR3) and water depth ( $A=$ transition depth $0 \mathrm{~cm}, B=75 \mathrm{~cm}$ water depth) for 10 weeks exposure

\begin{tabular}{|c|c|c|c|c|c|c|}
\hline \multirow[b]{2}{*}{ No. } & \multirow{2}{*}{$\begin{array}{c}\text { Stasiun/ } \\
\text { Station }\end{array}$} & \multicolumn{5}{|c|}{ Ulangan/Replay } \\
\hline & & 1 & 2 & 3 & 4 & $\begin{array}{c}\text { Rata-rata/ } \\
\text { Average }\end{array}$ \\
\hline 1. & TR1 A & $-0,216657$ & $-0,015187$ & $-0,246744$ & $-0,186569$ & $-0,16629$ \\
\hline 2. & TR1 B & $-0,341508$ & $-0,014827$ & $-0,370882$ & $-0,312133$ & $-0,25984$ \\
\hline 3. & TR2 A & $-0,296202$ & $-0,015588$ & $-0,327085$ & $-0,265319$ & $-0,22605$ \\
\hline 4. & TR2 B & $-0,281871$ & $-0,015187$ & $-0,311959$ & $-0,251784$ & $-0,2152$ \\
\hline 5. & TR3 A & $-0,347181$ & $-0,015187$ & $-0,377269$ & $-0,317093$ & $-0,26418$ \\
\hline 6. & TR3 B & $-0,337697$ & $-0,015187$ & $-0,367784$ & $-0,307609$ & $-0,25707$ \\
\hline
\end{tabular}

Hasil analisis lebih lanjut terhadap nilai tengah dengan Tuckey menunjukan bahwa laju dekomposisi (k) serasah pada stasiun TR1 kedalaman 0 (TR1 A) secara signifikan $(P<0,01)$ lebih rendah dibandingkan dengan TR1 kedalaman $75 \mathrm{~cm}$ (TR1 B), TR2 kedalaman 0 dan $75 \mathrm{~cm}$ (TR2 A dan B), dan TR3 kedalaman 0 dan $75 \mathrm{~cm}$ (TR3 A dan B) (Tabel 3). Selain itu, laju dekomposisi serasah pada stasiun TR2 kedalaman $75 \mathrm{~cm}$ (TR2 B) lebih rendah dibandingkan dengan stasiun TR3 kedalaman $0 \mathrm{~cm}$ (TR3 A). Fenomena ini berkaitan dengan fluktuasi beberapa parameter mutu air seperti kedalaman, suhu, kecerahan, jumlah padatan tersuspensi, organik karbon terlarut, bahan organik, daya hantar listrik, dan jumlah padatan terlarut. Hasil analisis cluster (Gambar 3) terhadap parameter mutu air tersebut mendapatkan adanya tiga kelompok.

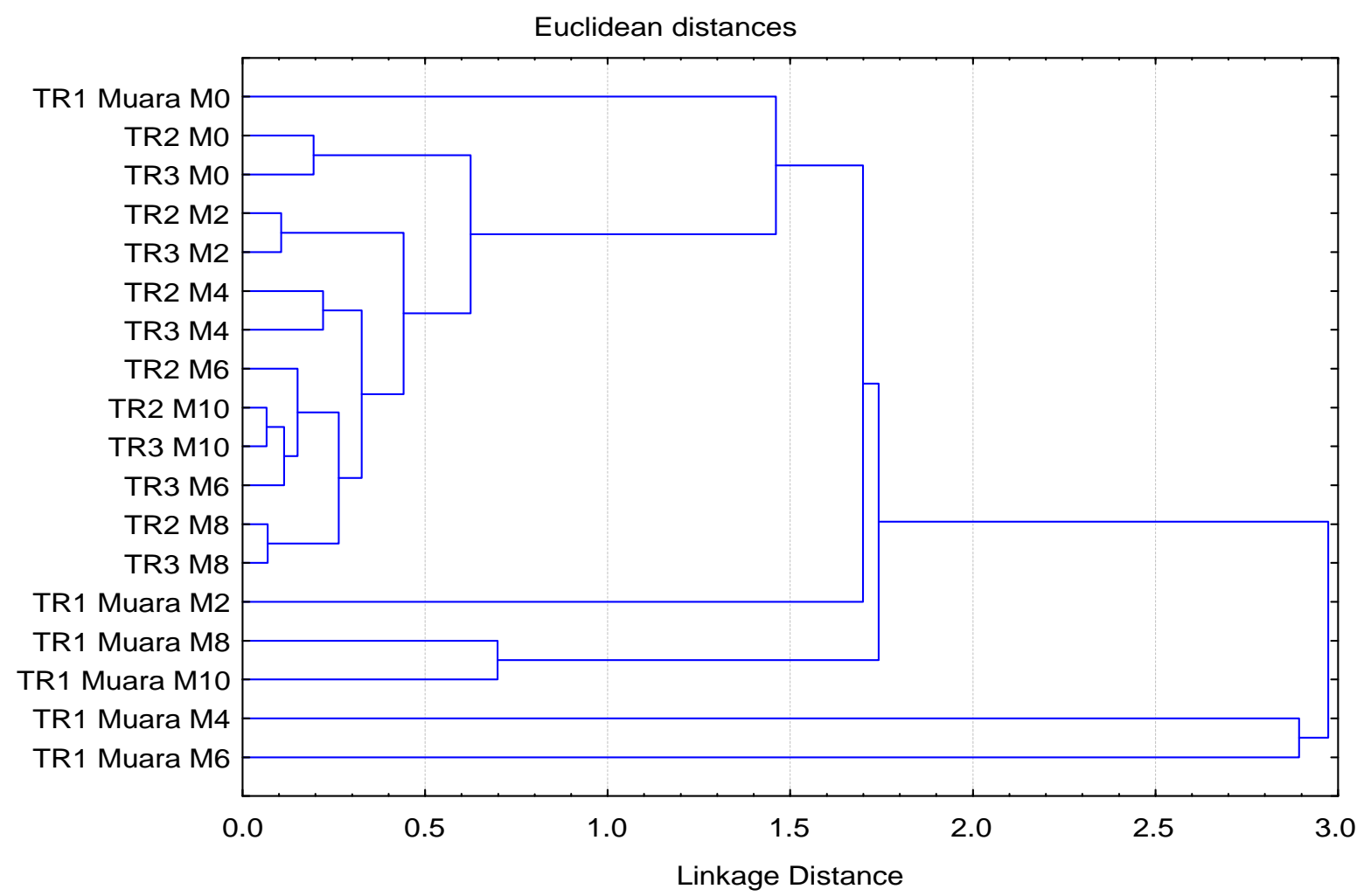

Gambar 3. Analisis kelompok (cluster) terhadap beberapa parameter kualitas air pada berbagai stasiun (TR1-3) dan minggu pengamatan (M2-10) di Teluk Rasau, Ogan Komering llir, Sumatera Selatan.

Figure 3. Cluster analysis on physical and chemical of water quality parameters at different sampling site (TR1-3) and at different sampling time (week 2-10/M2-10) in Teluk Rasau, Ogan Komering Ilir Regency, South Sumatera. 
Kelompok pertama terdiri atas stasiun TR1 muara M0, TR2 M0-TR2 M10, dan TR3 M0-TR3-M10. Kelompok kedua terdiri atas TR1 muara-M2, M8, M10, dan kelompok ketiga adalah TR1 Muara M4 dan M6. Kecuali pada TR1 M0, kelompok pertama dicirikan oleh kandungan oksigen terlarut yang relatif lebih tinggi yaitu pada kisaran $6,79-8,08 \mathrm{mg} / \mathrm{L}$ dan nilai $\mathrm{pH}$ pada kisaran 6,0-6,5. Kelompok kedua dicirikan oleh kedalaman air yang relatif lebih rendah $(70-95 \mathrm{~cm})$, suhu dan total suspended solids yang rendah (27$30,4^{\circ} \mathrm{C}$ dan $\left.0-10 \mathrm{mg} / \mathrm{L}\right)$ ) sedangkan kelompok ketiga dicirikan oleh tingginya nilai suhu, bahan organik, total suspended solids, dan daya hantar listrik, serta rendahnya kecerahan (Gambar 3 dan Lampiran 1-4). Relatif lebih tingginya kandungan oksigen terlarut pada stasiun pengamatan di Teluk Rasau Tengah dan Ujung (TR2 dan TR3) mempengaruhi laju dekomposisi daun serpang. Kecuali pada awal inkubasi (TR1 muara M0), laju dekomposisi serasah pada kedua stasiun pengamatan tersebut lebih tinggi dibandingkan dengan stasiun TR1 yang merupakan muara dari lebak Teluk Rasau yang berhubungan dengan Sungai Lempuing (Gambar 2). Studi yang dilakukan oleh Alvarez et al. (2001) menunjukan bahwa proses dekomposisi serasah berkaitan erat dengan tingginya kandungan oksigen terlarut dan unsur hara di perairan. Hasil analisis kandungan karbon, nitrogen total, dan fosfor total pada serasah vegetasi serpang selama 10 minggu mengindikasikan bahwa produksi karbon relatif hampir sama pada semua stasiun pengamatan dan waktu pengamatan, sedangkan fosfor total cenderung meningkat dan kandungan nitrogen total besarannya cenderung berfluktuasi baik antar stasiun dan waktu pengamatan (Lampiran 3). Ketiga fenomena tersebut diperkirakan berkaitan dengan keberadaan mikroba pengurai (jamur dan bakteri) pada serasah tersebut seperti yang dikatakan oleh Graca (2001) bahwa energi dan unsur hara yang terkandung dalam serasah terkonversikan pada biomassa mikroba pengurai.

Pada stasiun TR1 kedalaman $0 \mathrm{~cm}$ (batas air dan daratan) setelah dua minggu inkubasi atau minggu kedua sampai keenam pengamatan tidak tergenangi air (Lampiran 1). Rendahnya kedalaman air meningkatkan suhu air (Lampiran 2). Kondisi tanah yang kering dan peningkatan suhu air diperkirakan mengurangi proses dekomposisi bahan organik. Hasil studi Alvarez et al. (2001) juga menunjukan pola yang sama. Rendahnya laju dekomposisi pada stasiun TR2 kedalaman $75 \mathrm{~cm}$ dibandingkan TR3 kedalaman 0 $\mathrm{cm}$ (Tabel 3) diperkirakan berkaitan dengan adanya gangguan pada kerbau yang digembalakan di sekitar stasiun TR2.

Hasil analisis varians (anova) terhadap produksi invertebrata (makrobenthos) pada ketiga stasiun percobaan menunjukan tidak adanya perbedaan yang signifikan ( $P>0,5)$ (Gambar 4 dan Lampiran 6). Produksi makrozobenthos berfluktuasi selama 10 minggu pengamatan mengikuti pola fluktuasi daya hantar listrik, jumlah padatan tersuspensi, total fosfor, dan total nitrogen. Selain parameter kualitas air tersebut $\mathrm{di}$ atas peningkatan produksi makrozoobenthos pada minggu keenam dan delapan (Gambar 4) juga berkaitan dengan meningkatnya laju dekomposisi serasah daun serpang. 

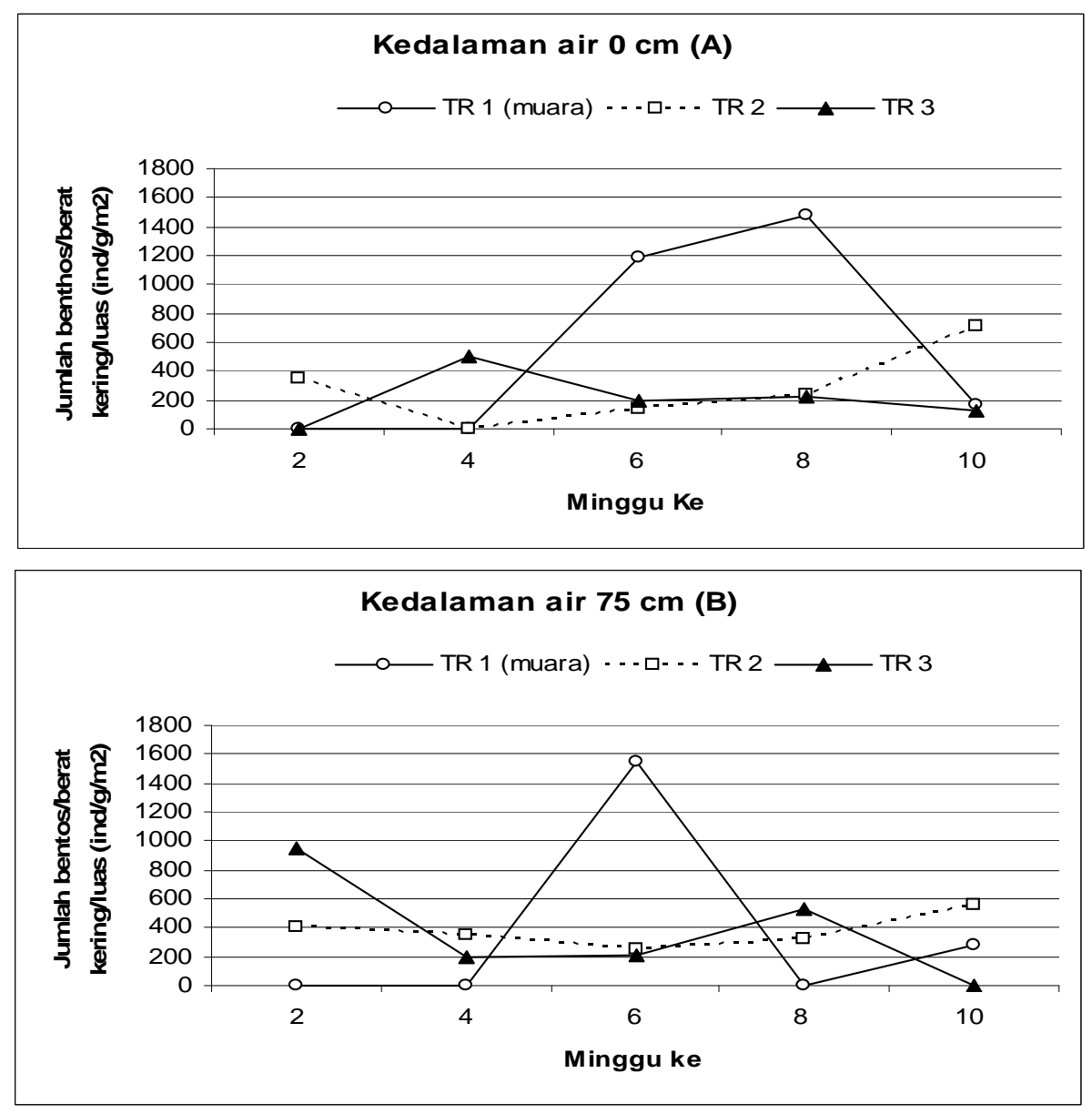

Gambar 4. Produksi makrozoobenthos ( $\mathrm{mg}$ bobot kering $\left./ \mathrm{m}^{2}\right)$ pada beberapa stasiun dan kedalaman air di Muara Teluk Rasau, Sungai Lempuing (TR1), Lebak Teluk Rasau (TR2 dan 3) selama 10 minggu.

Figure 4. Macrozoobenthos production ( $\mathrm{mg}$ dry weight $/ \mathrm{m}^{2}$ ) at different sampling sites and water depths in the inlet of Teluk Rasau connected to Lempuing River (TR1), Teluk Rasau (TR2 and TR3) for 10 weeks.

\section{KESIMPULAN}

1. Persentase serasah daun serpang yang terdekomposisi selama 10 minggu pada kisaran $40-55 \%$.

2. Koefisien laju dekomposisi serasah daun serpang pada muara Teluk Rasau yang berhubungan dengan Sungai Lempuing pada kedalaman $0 \mathrm{~cm}$ $(k=0,1586)$ lebih rendah dari stasiun lainnya baik pada kedalaman $0 \mathrm{~cm}$ ataupun $75 \mathrm{~cm}(\mathrm{k}=0,2076$ 0,2566).

3. Produksi makrozobenthos daripada Muara Teluk Rasau yang berhubungan dengan Sungai Lempuing baik pada kedalaman $0 \mathrm{~cm}$ ataupun 75 cm $\left(9,25 ; 117,25 \mathrm{mg}\right.$ bobot kering $\left./ \mathrm{m}^{2}\right)$ secara nyata lebih rendah dari stasiun lainnya $(17,75-22,08 \mathrm{mg}$ bobot kering $/ \mathrm{m}^{2} ; 260-807 \mathrm{mg}$ bobot kering $/ \mathrm{m}^{2}$ )

4. Kedalaman air, suhu, alkalinitas total dan unsur hara sangat mempengaruhi laju dekomposisi serasah dan produksi makrozoobenthos.

\section{PERSANTUNAN}

Tulisan ini merupakan kontribusi dari kegiatan hasil riset laju dekomposisi bahan organik dan produksi invertebrata air di suaka perikanan Teluk Rasau, Sumatera Selatan, T. A. 2009, sumber dana berasal dari hibah penelitian bagi peneliti dan rekayasa kerja sama Departemen Pendidikan Nasional dan Departemen Kelautan dan Perikanan. 


\section{DAFTAR PUSTAKA}

Alvarez, S., E. Rico, MaC. Guerrero, \& C. Montes. 2001. Decomposition of Juncus maritimus in Two Shallow Lakes of Doñana National Park. Internat. Rev. Hydrobiol. 86 (4-5): 541-554.

Braioni, M. G., B. Gumiero, \& G. Salmoiraghi. 2001. Leaf bags and natural leaf packs: Two approaches to evaluate river functional characteristics. Internat. Rev. Hydrobiol. 86 (4-5): 439-451.

Findlay, S. E. G. \& R. L. Sinsabaugh. 2003. Aquatic Ecosystems: Interactivity of Dissolved Organic Matter. Academic press. Ney York. 512 pp.

Graça, M. A. S. 2001. The role of invertebrates on leaf litter decomposition in streams-a review. Internat. Rev. Hydrobiol. 86: 383-393.

Hoggarth, D. D., Cowan, V. J., Halls, A. S., AeronThomas, M., McGregor, J. A., Garaway, C. A., Payne, A. I., \& Welcomme, R. L. 1999. Management guidelines for Asian floodplain river fisheries. Part 2. Summary of DFID Research. FAO Fisheries Technical Paper. No. 384/2. Rome. FAO. 1999. 117 pp.

Husnah. 2008. Potential threat to the floodplain ecosystem of Lempuing River, South Sumatera.
In Monograph Of Lubuk Lampam Floodplain. Research Institute for Inland Water Fisheries. 149155.

Kaplan, L. A. \& J. D. Newbold. 2003. The role of monomers in stream ecosystem metabolism. In Aquatic Ecosystems: Interactivity of Dissolved Organic Matter. Findlay and Sinsabaugh (eds). Academic press. New York. 97-120.

Thomas, M. A., A. S. Hall, D. D. Hoggarth, S. Koeshendrajana, S. Sarnita, A. D. Utomo, \& Samuel. 1998. Selection Criteria and CoManagement Guidelines for Harvest Reserves in Tropical River Fisheries. UK Department for International Development Fisheries Management Science Program Project R7043. and Central Research institute for Fisheries. Indonesia. 55 pp.

Whitten, A. J., S. J. Damanik, J. Anwar, \& N. Hisyam. 1987. The Ecology of Sumatera. Gajah Mada University Press. 583 pp.

Welcomme, R. \& Halls, A. 2004. Dependence of tropical river Fisheries on flow. Edited by Robin L. Welcomme \& T. Petr. Proceeding of the Second International Symposium on the Management of Large Rivers for Fisheries 11-14 February 2003. Phnom Penh. Kingdom of Cambodia. 267-283. 
Lampiran 1. Tinggi (kedalaman) air pada bagian tepi (A) dan tengah (B) pada tiga stasiun di Teluk Rasau Appendix 1. Water depth at two sampling points the edge $(A)$ and center $(B)$ at three sampling sites of Teluk Rasau
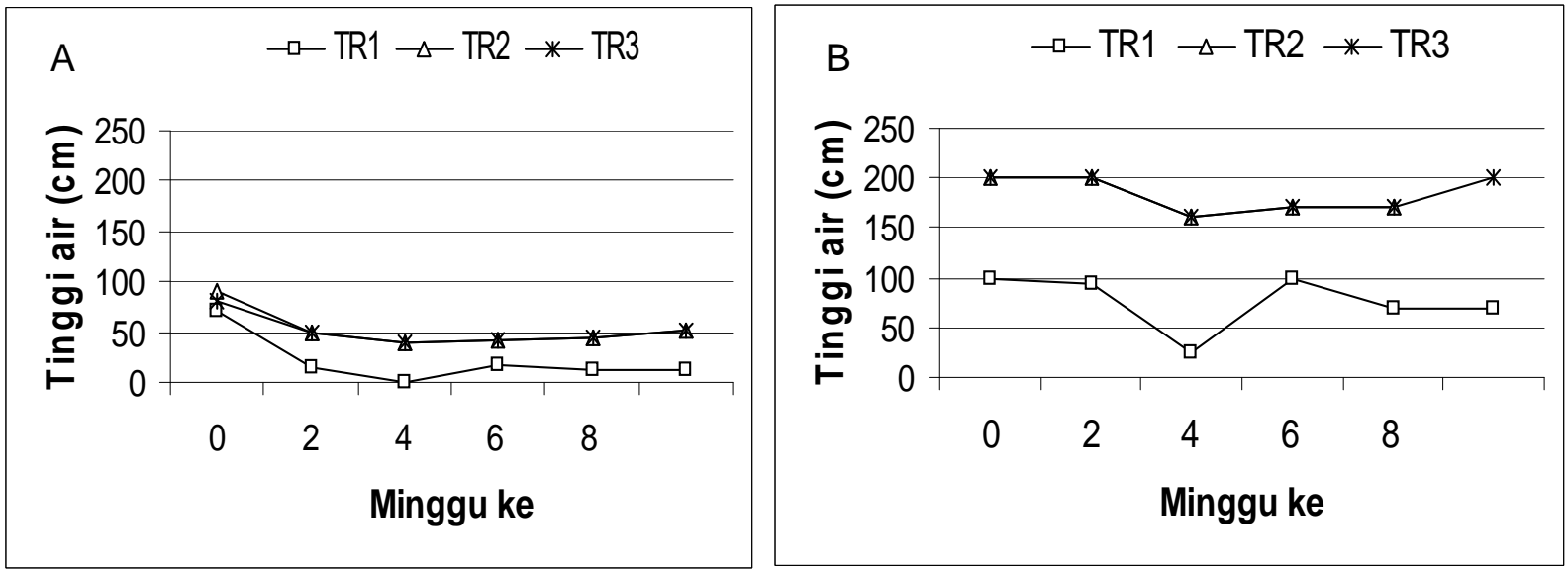

Lampiran 2. Nilai parameter suhu air, oksigen terlarut, organik karbon terlarut, dan bahan organik pada tiga stasiun di Teluk Rasau

Appendix 2. Water temperature, dissolved oxygen, dissolved organic carbon, and organic matter at three sampling sites in Teluk Rasau

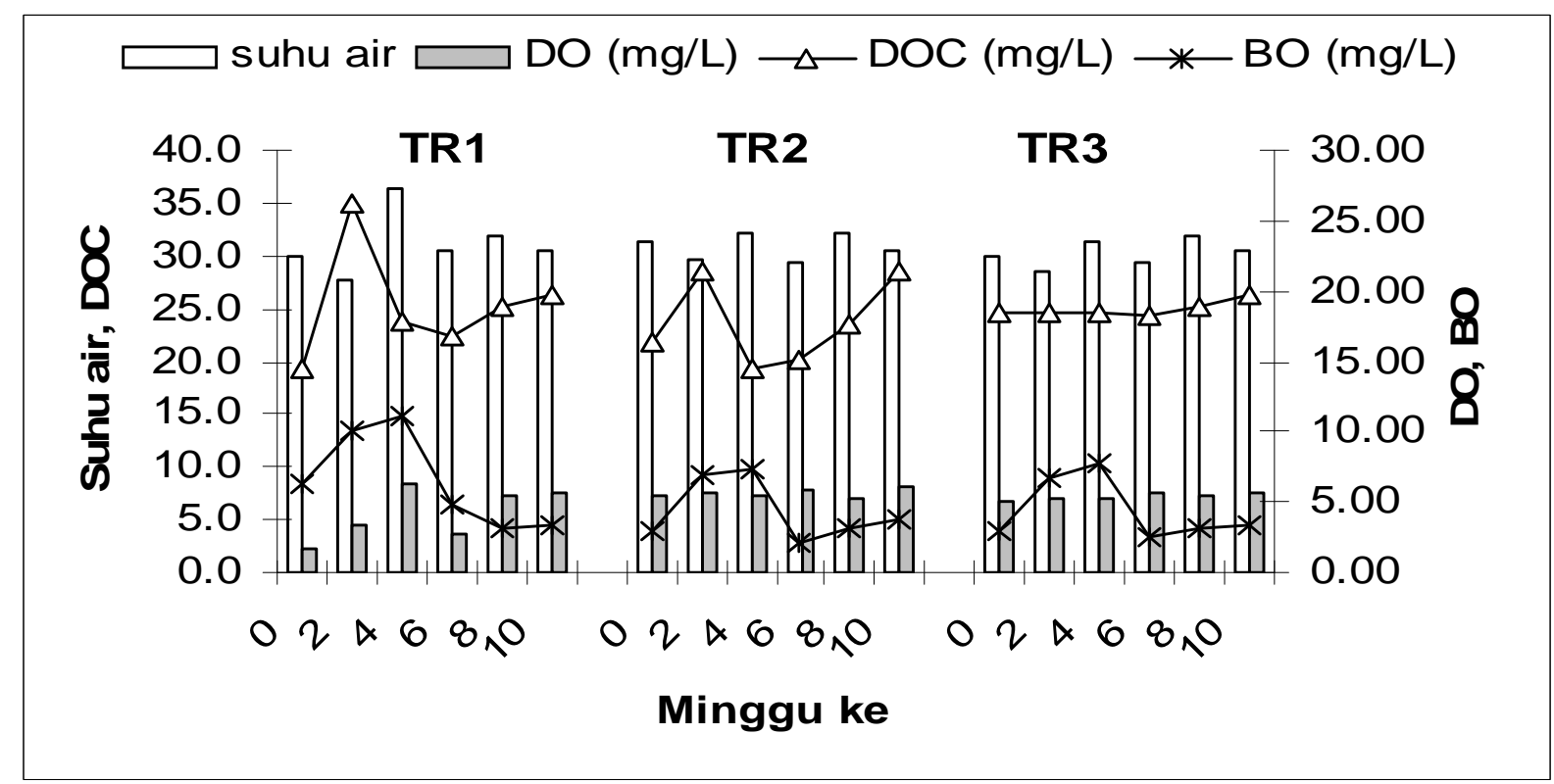


Lampiran 3. Kandungan karbon total, nitrogen total, dan fosfor total dalam serasah vegetasi serpang pada berbagai stasiun pengamatan (TR1-TR3), berbagai kedalaman air (kedalaman air 0 $\mathrm{cm} / \mathrm{A}$ dan kedalaman air $75 \mathrm{~cm} / \mathrm{B}$ ), dan berbagai waktu pengamatan (minggu 0-10)

Appendix 3. Total carbon, nitrogen, and phosphorus content of leaf litter at station TR1, TR2, and TR3 at water depth 0 (transition water and land/A), water depth $75 \mathrm{~cm}(B)$ and at week 0, 2, 6, and 10
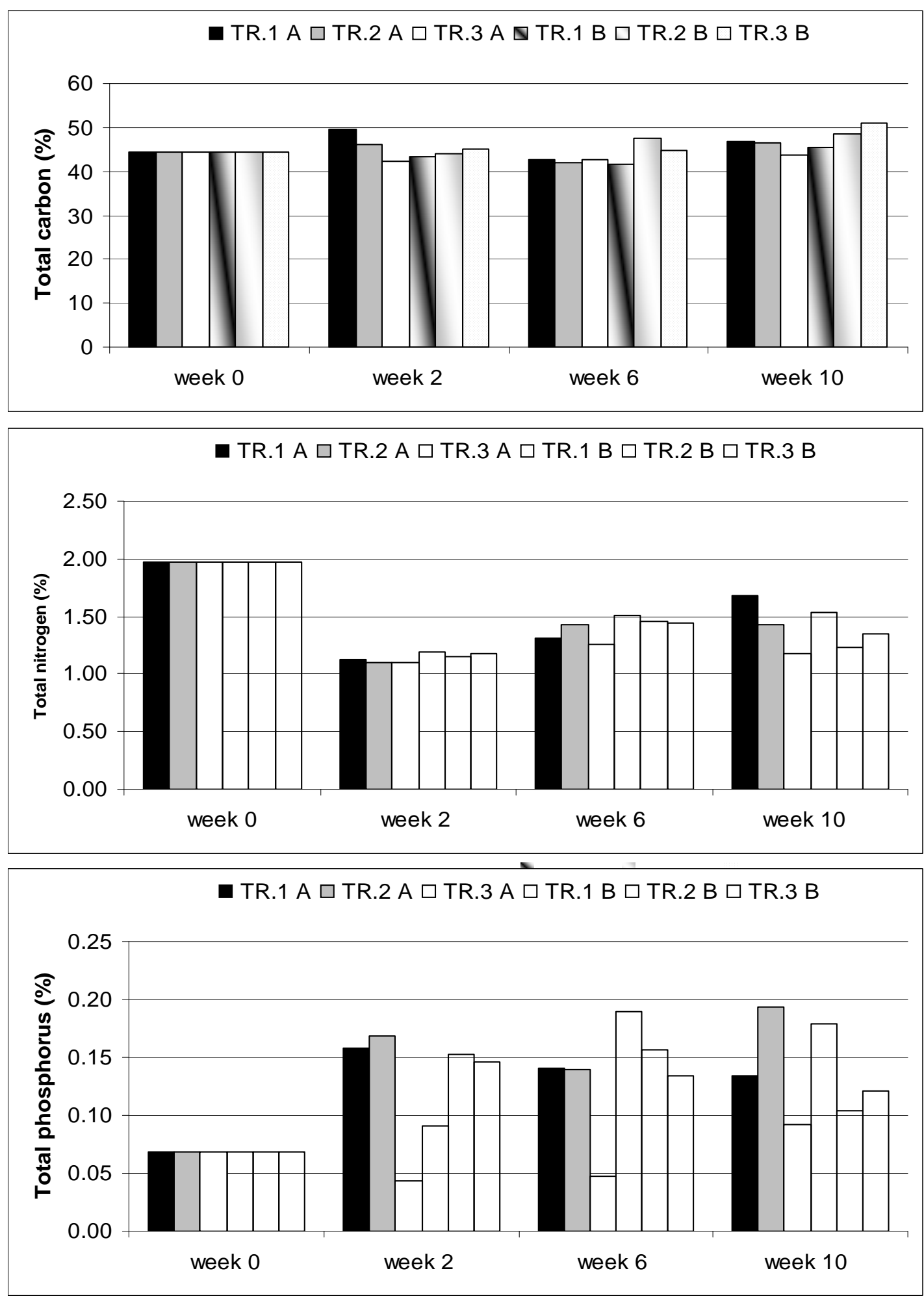
Lampiran 4. Nilai parameter $\mathrm{pH}$, alkalinitas total, hardness, daya hantar listrik, jumlah padatan tersuspensi, total fosfor, dan total nitrogen pada tiga stasiun di Teluk Rasau

Appendix 4. $\quad p H$ value, total alkalinity, total hardness, conductivity, total suspended solids, total phosphorus, and total nitrogen of water at three sampling sites in Teluk Rasau

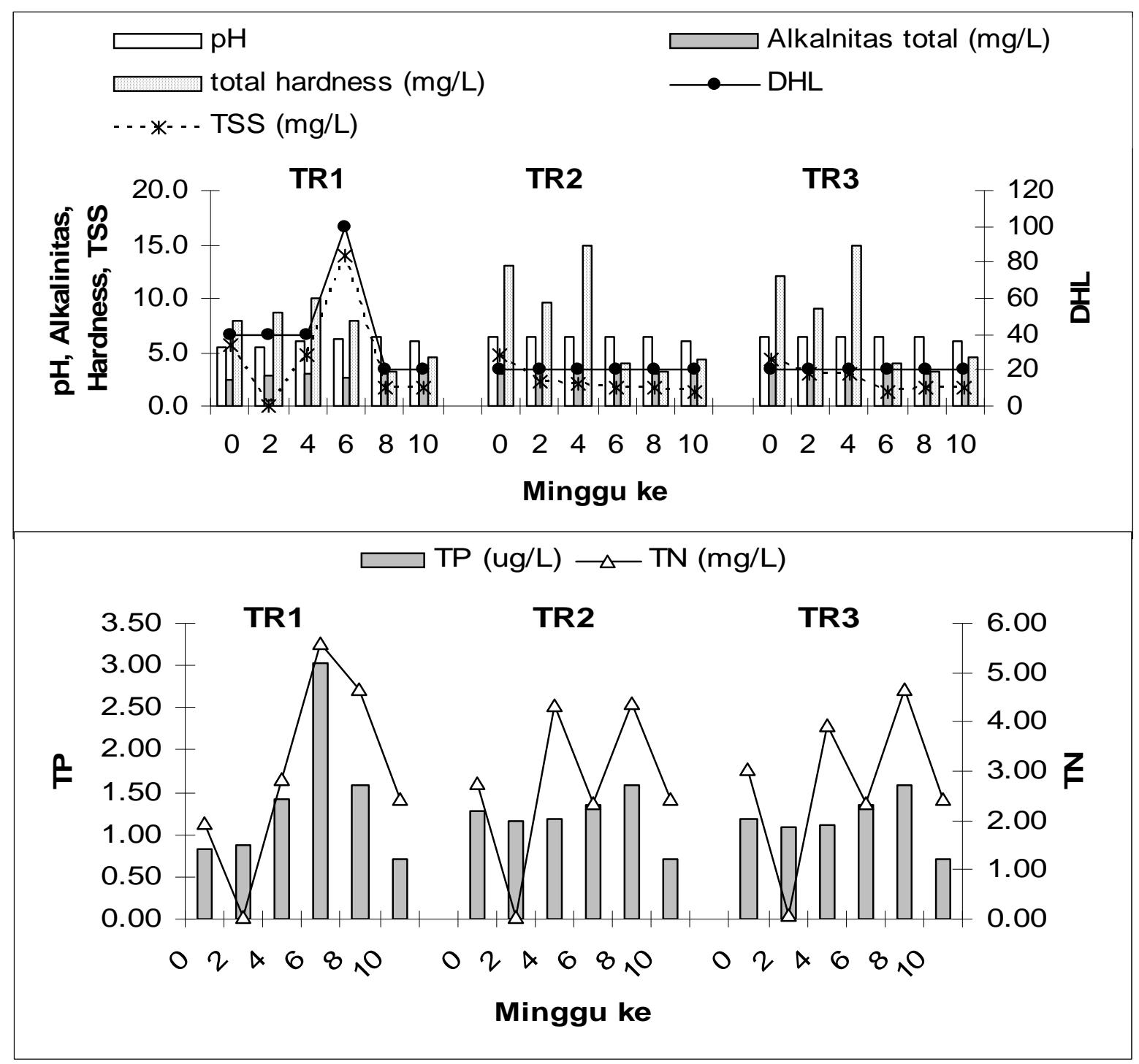

Lampiran 5. Hasil analisis kovarian (ANCOVA) laju dekomposisi serasah pada berbagai stasiun, kedalaman air di Teluk Rasau, Ogan Komering Ilir, Sumatera Selatan, bulan September sampai Desember 2009

Appendix 5. Analysis of covarians on decomposition rate of serpang leaves at different sampling sites and water depths in Teluk Rasau, Ogan Komering llir Regency, South Sumatera from September to December 2009

\begin{tabular}{lccccc}
\hline Parameter/Parameter & SS & Degr. of & MS & F & p \\
\hline Intercept & 0,002224 & 1 & 0,002224 & 0,4821 & 0,488890 \\
Minggu ke & 2,291896 & 1 & 2,291896 & 496,8616 & 0,000000 \\
kedalaman & 0,253035 & 5 & 0,050607 & 10,9711 & 0,000000 \\
Error & 0,521240 & 113 & 0,004613 & & \\
\hline
\end{tabular}

Tukey HSD test; variable Dekomposisi (dekomposisi)

Probabilities for Post Hoc Tests

Error: Between MS $=00461, \mathrm{df}=113.00$ 


\begin{tabular}{cccccccc}
\hline No. & Kedalaman/Depth & $\mathbf{1}$ & $\mathbf{2}$ & $\mathbf{3}$ & $\mathbf{4}$ & $\mathbf{5}$ & $\mathbf{6}$ \\
\hline 1. & TR1 A & & 0,000123 & 0,001070 & 0,034468 & 0,000120 & 0,000121 \\
2. & TR1 B & 0,000123 & & 0,838509 & 0,175358 & 0,980897 & 0,999855 \\
3. & TR2 A & 0,001070 & 0,838509 & & 0,867191 & 0,426109 & 0,706394 \\
4. & TR2 B & 0,034468 & 0,175358 & 0,867191 & & 0,034046 & 0,105973 \\
5. & TR3 A & 0,000120 & 0,980897 & 0,426109 & 0,034046 & & 0,997870 \\
6. & TR3 B & 0,000121 & 0,999855 & 0,706394 & 0,105973 & 0,997870 & \\
\hline
\end{tabular}

Keterangan/Remarks: huruf miring adalah signifikan $(\mathrm{P}, 0,01)$

Lampiran 6. Hasil analisis varian (ANOVA) produksi makrozobenthos pada berbagai stasiun, kedalaman air di Teluk Rasau, Ogan Komering llir, Sumatera Selatan, bulan September sampai Desember 2009

Appendix 6. Analysis of varian (ANOVA) macrozoobenthos production at different sampling sites and water depth in Teluk Rasau, Ogan Komering Ilir Regency from September to December 2009

\begin{tabular}{lccccc}
\hline \multicolumn{1}{c}{ Parameter/Parameter } & SS & Degr. of & MS & F & P \\
\hline Intercept & 0,001154 & 1 & 0,001154 & 6,213354 & 0,014509 \\
Stasiun & 0,000431 & 2 & 0,000215 & 1,159681 & 0,318227 \\
Kedalaman & 0,000033 & 1 & 0,000033 & 0,179330 & 0,672960 \\
Minggu ke & 0,001267 & 4 & 0,000317 & 1,704711 & 0,155877 \\
Stasiun*kedalaman & 0,000705 & 2 & 0,000353 & 1,897849 & 0,155841 \\
Stasiun $^{\star}$ minggu ke $_{\text {Kedalaman*minggu ke }}$ & 0,001772 & 8 & 0,000221 & 1,192157 & 0,312689 \\
Stasiun*kedalaman*minggu ke & 0,000374 & 4 & 0,000094 & 0,503960 & 0,732892 \\
Error & 0,001489 & 8 & 0,000186 & 1,001677 & 0,440506 \\
\hline
\end{tabular}

